\title{
Performance of indigenous protein sources as diets for tilapia under laboratory condition
}

\author{
ERLINDA S. GANZON-NARET, ${ }^{1}$ SHUNSUKE KOSHIO, ${ }^{2}$ SHIN'ICHI TESHIMA, ${ }^{2}$ AND MANABU ISHIKAWA ${ }^{2}$ \\ ${ }^{1}$ University of the Philippines in the Visayas, College of Fisheries and Ocean Sciences, Institute of Aquaculture, \\ Miag-ao, Iloilo, Philippines, 5023 and $^{2}$ Faculty of Fisheries, Kagoshima University, Shimoarata 4-50-20, \\ Kagoshima, Japan
}

SUMMARY: A 90-day feeding experiment was conducted in the laboratory to evaluate the performance of three potential protein sources, swamp cabbage, sweet potato leaf meals and blood meal either used singly or in combination in a diet for tilapia fingerlings. Five test diets containing approximately $\mathbf{4 0} \%$ crude protein were prepared. A diet composed of fish meal and soybean meal as sources of protein was used as control. Treatments were arranged in a completely randomized design at three replicates and each diet was fed to tilapia fingerlings at a rate of $10 \%, 8 \%$ and $6 \%$ of the total biomass daily for the $1^{\text {st }}, 2^{\text {nd }}$ and $3^{\text {rd }}$ months of feeding. In terms of specific growth rates (\%) fish fed Diet 4 containing $15 \%$ replacement of fish meal protein from blood meal gave the best growth performance, however this was comparable or similar to the results obtained in Diet 5 from a combination of swamp cabbage, sweet potato leaf meal and blood meal and from those of the control fish in Diet 1 . There was no significant difference $(P>0.05)$ in the feed conversion ratio and survival rates among the various dietary treatments. The highest PER values were obtained in Diets 4 and 5, while Diet 2 containing $15 \%$ replacement from swamp cabbage leaf meal produced the lowest followed by Diet 3 , replacement came from sweet potato leaf meals.

KEYWORDS: indigenous, protein, tilapia, leaf meals

\section{INTRODUCTION}

Tilapias are major protein source in many developing countries. They are easily cultured and exhibit good growth performance in ponds, rice paddies and cages. Owing to its good taste and higher acceptability to consumers, tilapia has become a favorite food fish.

The success in the intensification of tilapia culture among fish culturists can be brought about by the development of practical low cost efficient diets. The protein source in formulating artificial feed for most fish and crustaceans is fish meal. ${ }^{1)}$ But due to the rising cost and uncertain availability of fish meal, there is a need to evaluate the potential of locally available feed ingredients as alternative protein source for fish feeds. Considerable research has focused on the use of plant and animal proteins as substitute for fish meal in the formulated diets of fish. A number of these ingredients are various leaf meals which include sweet potato or kamote (Ipomea batatas) ipil-ipil (Leucaena leucocephala), swamp cabbage or kangkong (Ipomea reptans), cassava and water hyacinth as plant protein sources ${ }^{2,3)}$ and the use of blood meal, silk worm pupae and poultry offal meal ${ }^{4)}$ as animal protein sources had been carried out as partial or complete dietary replacement of fish meal for other fish species. However there is a scarcity of information on the use of plant and animal protein either singly or in combination as dietary protein sources for tilapia. This study evaluates three potential protein sources, swamp cabbage and sweet potato leaf meals and blood meal as partial replacement of fish meal protein in a diet for tilapia fingerlings.

\section{MATERIALS AND METHODS}

Diet Preparation

Blood meal was prepared from cow's blood collected from a slaughterhouse, and this was kept in the air convection oven (Ehnet type) at $80^{\circ} \mathrm{C}$ overnight and then dried in air. After drying, the blood was ground (Osterizer) and sieved.

The leaves of swamp cabbage and sweet potato were soaked in water for 24 hours. These were rinsed and arranged flat thinly in the aluminum pans to be 
dried in the air convection oven at $60^{\circ} \mathrm{C}$. The leaves were then ground and sieved using 60 mesh screen.

Five isonitrogenous ( $40 \%$ protein) diets were formulated to evaluate leaf meals and blood meal as dietary protein sources for tilapia fingerlings. The major protein sources used in the diet are the the fish meal and soybean meal. Fish meal was incorporated at $39 \%$ in test diets no. $2-5$ providing $25 \%$ crude protein and this was partially replaced by various leaf meals and blood meal respectively at $15 \%$ either solely or a combination of both plant and animal proteins. The amount of leaf meals incorporated in Diets no. $2-3$ ranged from $17.79 \%-18.17 \%$ of the diet. .Dietary treatments are as follows: The control diet (diet 1) contained fish meal and soybean meal. In diets no. $2-3,15 \%$ of the fish meal protein was replaced singly by the swamp cabbage and sweet potato leaf meals respectively, in diet no. $4,15 \%$ replacement of fish meal protein came from blood meal, whereas in diet 5, swamp cabbage, sweet potato leaf meals and blood meal were mixed at 1:1:1 protein ratio to replace $15 \%$ of the fish meal protein. Diets were prepared by first mixing the dry ingredients one at a time and then blending in the oils. The breadflour was gelatinized and added to the mixture. The moist mixture was extruded using a meat grinder with a 2$\mathrm{mm}$ die. The pellets were dried in the oven at $40-60^{\circ} \mathrm{C}$ and the dry pellets were crushed to appropriate sizes and stored at $4^{\circ} \mathrm{C}$ before feeding.

Table 1. Composition ( $\mathrm{g} / 100 \mathrm{~g}$ diet), nutrient contents (\%) and cost per $\mathrm{kg}$. of experimental diets (US $\$=$ P40.00).

\begin{tabular}{lrrrrr}
\hline Ingredients & Diet 1 & Diet 2 & \multicolumn{1}{c}{ Diet 3 } & \multicolumn{1}{c}{ Diet 4 } & \multicolumn{1}{c}{ Diet 5 } \\
\hline Fish meal & 45.94 & 39.04 & 39.04 & 39.04 & 39.04 \\
Soybean meal & 15.31 & 15.31 & 15.31 & 15.31 & 15.31 \\
Swamp cabbage leal meal & & 17.79 & & & 5.93 \\
Sweet potato leat meal & & & 18.17 & & 6.06 \\
Blood meal & & & & 5.46 & 1.82 \\
Rice bran & 11.25 & 19.98 & 19.38 & 6.61 & 15.56 \\
Breadtiour & 22.50 & 2.88 & 3.10 & 28.58 & 11.28 \\
Vit-mineral mix & 3.00 & 3.00 & 3.00 & 3.00 & 3.00 \\
Cod liver oil & 2.00 & 2.00 & 2.00 & 2.00 & 2.00 \\
Analyzed (\% dry matter) & & & & & \\
Crude protein & 39.98 & 39.75 & 39.71 & 39.82 & 39.78 \\
Crude lipid & 10.82 & 10.57 & 10.61 & 10.80 & 10.76 \\
Ash & 11.30 & 10.67 & 12.08 & 10.79 & 11.21 \\
Cost/kg diet & 50.20 & 45.10 & 46.50 & 48.50 & 46.50 \\
\hline
\end{tabular}

The feed ingredients of protein sources (Table 2) and the experimental diets were analyzed for protein content using the Kjeldahl distilling apparatus (Kjeltec system 1002, Tecator, Sweden), the crude fat was determined using the Ether Extraction Method, moisture was obtained by drying the samples in the oven (Libror, AEL 200-Shimadzu) and ash content was determined by incinerating the sample in a furnace at $550^{\circ} \mathrm{C}$ (Hayashi Denko Co. Ltd. $0-1200^{\circ} \mathrm{C}$ ).

Table 2. Proximate analysis (\%) of protein sources

\begin{tabular}{lrrr}
\hline Protein sources & Crude Protein & Crude Lipid & \multicolumn{1}{c}{ Ash } \\
\hline Fish meal & 65.22 & 5.70 & 11.20 \\
Soybean meal & 47.79 & 15.20 & 9.10 \\
Swamp cabbage leaf meal & 25.29 & 5.60 & 14.00 \\
Sweet potato leat meal & 24.76 & 5.20 & 12.80 \\
Cow's blood meal & 82.33 & 4.65 & 6.02 \\
Rice bran & 11.61 & 12.26 & 10.88 \\
Breadflour & 6.32 & 1.62 & 0.72 \\
\hline
\end{tabular}

\section{Rearing and feeding scheme}

Tilapia fingerlings were obtained from the Freshwater Aquaculture Station (FAS) in Miag-ao, Iloilo, Philippines. Prior to the feeding experiment, the fingerlings were acclimated to the laboratory condition for 15 days at the UPV Hatchery and were fed the control test diet. The fish $(1.81-2.28 \mathrm{~g})$ were stocked randomly at a density of 10 fingerlings/aquarium with three replications for each treatment. Each aquarium was filled with $50 \mathrm{l}$ of aerated freshwater. All fish were fed thrice daily at 0900,1300 and $1700 \mathrm{hrs}$ at a rate of $10 \%, 8 \%$ and $6 \%$ of the body weight for the 1st,2nd and 3rd months of feeding.

The feeds were given slowly into the aquaria and the acceptability of the fish to the different diets were observed. Due to the difficulty in recovering feed particles from the water column, the amount of feeds given was assumed to be the amount of feed consumed. The fish were sampled from each aquarium every two weeks and the weights were taken using a digital balance (Mettler Toledo). Specific growth rate (SGR), protein efficiency ratio (PER), feed conversion ratio (FCR) and survival were evaluated to determine the efficiency of the diets.

\section{Water management}

The water was changed daily, accumulated feeds and wastes were siphoned using a 2-mm diameter plastic tubing. Water temperature ranged from 25.88 to $26.06^{0} \mathrm{C}, \mathrm{pH}$ 6.96-7.14, dissolved oxygen from 5.82 to $6.14 \mathrm{mg} / \mathrm{l}$..

\section{Statistical analysis}

All data were analyzed statistically using one way analysis of variance (ANOVA) and Duncan's Multiple Range Test (DMRT). 


\section{RESULTS}

Figure 1 shows the growth pattern of tilapia cultured at different diets for 90 days. Fish fed the control diet (diet 1) attained the highest final body weight among the different dietary treatments and the lowest was obtained with diet 2 , contributed by the swamp cabbage leaf meal. The growth was more or less similar up to 45 days and a clear trend was observed during the 60-day rearing period. The estimated total cost of feed ingredients per kilogram is presented in Table 1. Diet 1 was the most expensive while diet 2 was the cheapest.

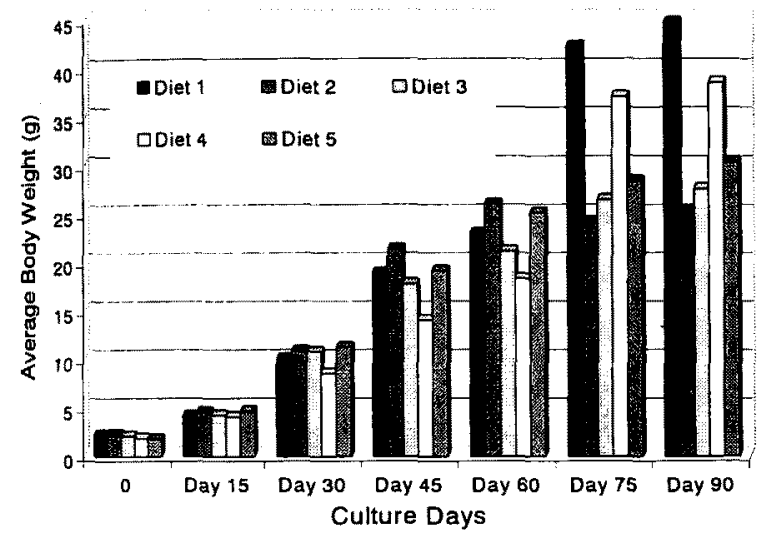

Fig. 1 Growth pattern of tilapia cultured at different dietary treatments for 90 days.

The response of tilapia fingerlings to the various experimental diets is shown in Table 3. From a mean initial body weight of $1.81-2.28 \mathrm{~g}$. they grew to 27.62 $44.78 \mathrm{~g}$. in 90 days. . The specific growth rates (SGR) of tilapia fingerlings in Diet 1,4 and 5 differ significantly $(\mathrm{P}<0.01)$ from Diet 2 but not with Diet 3 .

Table 3. Response of tilapia fingerlings to the various experimental diets

\begin{tabular}{|c|c|c|c|c|c|c|}
\hline Diet No. & $\begin{array}{r}\text { Mean } \\
\text { Initial Wt. }\end{array}$ & $\begin{array}{c}\text { Mean } \\
\text { Final Wt (g) }\end{array}$ & $\begin{array}{l}\text { SGR } \\
\text { (\%/day) }\end{array}$ & FCA & PER & $\begin{array}{c}\text { Survival } \\
(\%)\end{array}$ \\
\hline 1 & 2.28 & 44.78 & $3.29^{\mathrm{ab}}$ & 1.69 & $1.59^{6}$ & 70.00 \\
\hline 2 & 2.26 & 25.36 & $2.57^{\circ}$ & $2.3 t^{4}$ & 1.17 & 76.67 \\
\hline 3 & 2.12 & 27.67 & $2.85^{b c d}$ & 1.67 & $1.50^{* b}$ & 86.67 \\
\hline 4 & 1.91 & 38.56 & 3.38 ab & 1.22 & $2.06^{*}$ & 86.67 \\
\hline 5 & 1.81 & 30.39 & $3.12^{\mathrm{ab}}$ & 1.22 & 2.04 & 96.67 \\
\hline
\end{tabular}

Means in column with similar superscript are not significantly different $(\mathrm{P}<0.05)$.

The over-all performance in terms of feed conversion ratio (FCR) showed that the most efficient per gain ratio of 1.22 were obtained with Diet nos. 4 and 5 while the poorest FCR was obtained with Diet 2 but the difference were not significant $(P>0.05)$.

The protein efficiency ratio (PER) showed more or less similar response to those of weight gain $(\%)$ and SGR. PER which ranged between 1.17 and 2.06 was significantly $(\mathrm{P}<0.05)$ different among the treatment groups. Diet 5 gave an excellent fish survival of $96.67 \%$ but this was not significantly $(\mathrm{P}>0.05)$ different from other treatments including Diet 1 at $70 \%$. Most mortalities were attributed to the accidental jumping behavior of fish from the aquaria which were not recovered during the feeding experiment.

\section{DISCUSSION}

The present study shows that the use of swamp cabbage and sweet potato leaf meals as partial substitute for fish meal protein at $15 \%$ level (Table 3 ) resulted in reduced specific growth rates (\%) and feed efficiency. This is possibly due to low levels of essential amino acids such as methionine, cystine and lysine present in these plant ingredients. ${ }^{5)}$

It is noteworthy that fish did not accept well swamp cabbage (Diet 2) and sweet potato (Diet 3) leaf meals. Most of the feeds given was usually found uneaten. Therefore, the poor performance of tilapia in terms of feed utilization efficiency may have been related to the presence of anti-nutritional factors and poor digestibility. ${ }^{6}$ Plant proteins are known to contain anti-nutritional factors. ${ }^{7)}$ Lin and Chen ${ }^{8)}$ reported that sweet potato leaves contained tannins and low levels of trypsin inhibitor. This suggests that proper caution must be exercised in the processing of leaf meals to render plant proteins available. Similar findings on growth depression have been observed in giant tiger prawn (Penaeus monodon) ${ }^{9)}$ and tilapia (Oreochromis niloticus) ${ }^{10)}$ when such diets are supplemented with large concentration of unsoaked leucaena leaves. Hasan et al. ${ }^{11)}$ found significant histopathological changes in the liver of carp fingerlings fed unsoaked leucaena. Although the leaves of the plant ingredients were soaked in water for 24 hours, the process may not be adequate in removing the anti-nutritional factors in swamp cabbage and sweet potato leaf meals which make them unpalatable and reduced feed intake.

Cow's blood meal used in the present study was dried in the air convection oven at $80^{\circ} \mathrm{C}$ overnight. It 
appears that it has a crude protein content of $82.33 \%$ higher than that of the fish meal which is $65.22 \%$ (Table 1). Despite of its high nutritive value, little information has been published on the use of cow's blood meal. The inclusion of cow's blood meal in Diet 4 at $15 \%$ level of replacement or in combination with swamp cabbage and sweet potato leaf meals (Diet 5) resulted in improved growth rate, feed conversion and protein efficiency ratio compared to the fish meal-soybean meal based control diet (Diet 1).

The better growth performance could be attributed to the good amino acid profile of the diet, whereas the combination of cow's blood with two leaf meals in Diet 5 might have given a good balance in essential amino acids required for tilapia, and at the same time the use of cow's blood could compensate for essential amino acid deficiencies in leaf meals.

Other reports have indicated that dietary supplementation of crystalline L-amino acids could improve the nutritional value of both plant and animal feed ingredients, ${ }^{13)}$ and the search for better attractants to improve palatability. ${ }^{14)}$

In conclusion, the results of the present study revealed that blood meal or combination of blood meal with leaf meals could be a potential substitute for fish meal protein. However, in this study 15\% replacement of fish meal protein by these indigenous ingredients in a $40 \%$ protein diet, did not have a remarkable influence on the growth of tilapia under laboratory condition for 90 days. Further studies on growth trials of tilapia in ponds using the same feeds should be encouraged and perhaps different dietary levels of fish meal lower than 39\% incorporation in the diet shall be tested to determine how effective is the replacement of fish meal protein with various leaf meals and blood meal. The diet containing swamp cabbage and sweet potato leaf meals could be an effective alternative protein sources for fishmeal in tilapia provided these are supplemented with essential amino acids and additional processing shall be done to improve its palatability.

\section{ACKNOWLEDGMENTS}

This research was funded through a grant from the University of the Philippines in the Visayas (UPV) Miag-ao, Iloilo, Philippines. Proximate analyses was determined at the Laboratory of Aquatic Nutrition, College of Fisheries, Kagoshima University, Japan under the DOST-JSPS CUP Research Program. The assistance of Carmen L. Gempis, Robert Flor, Ambrosio Gonzales and Mercy N. Fabrigas is gratefully acknowledged.

\section{REFERENCES}

1. Lovell T. Feed formulation and processing. In: Lovell, $T$ (ed.) Nutrition and Feeding of Fish.. Van Nostrand Reinhold Publication, New York. 1989; pp 107-127.

2. Ng WK, Wee KL. The nutritive value of cassava leaf meal in pelleted feed for Nile tilapia. Aquaculture 1989; 83: 45-58.

3. Borlongan IG, Coloso RM. Leaf meals as protein sources in diets for milkfish, Chanos chanos (Forskal). In: De Silva, SS (ed.). Fish Nutrition Research in Asia Proceedings of the Fifth Asian Fish Nutrition Workshop, Manila. Philippines Asian Fisheries Society. Asian Fish Soc. Spec. Publication. 1994; 9: 63-68.

4. Habib MAB, Hasan MR, Akand AM. Evaluation of silkworm pupae as dietary protein sources for Clarias batrachus. Project Report I of IFS Project. 1992; pp 15

5. Penaflorida V. An evaluation of indigenous protein sources as potential component in the diet formulation for tiger prawn, Penaeus monodon, using essential amino acid index (EAAI). Aquaculture 1989; 83; 319-330.

6. Tacon AGJ, Jackson A. Utilization of conventional and unconventional protein sources in practical feeds. In C.B. Cowey, A.M. Mackie and J.G. Bell (eds.). Nutrition and feeding in fish.. Academic Press, London. 1985; pp 119-145.

7. Tacon AG. Standard Methods for the Nutrition and Feeding of Farmed Fish and Shrimp, Vol. 3. Feeding Methods. Argent Laboratories Press, Redmond, WA, USA.1990; pp207

8. Lin SSM, Chen DM. Sweet potato production and utilization in Asia and the Pacific. In Bouwkang J.C. (ed.) Sweet Potato Products. A Natural Research for the Tropics, CRC Press. 1985: pp 139-148.

9. Pascual FP, Tabbu NS. Ipil-ipil (Leucaena leucocephala) leaves as plant protein source in prawn diets. Aquaculture Department, Seafdec. 1990: Q. Res. Rep. 4 (1): 1-4.

10. Wee KL, Wang SS. Nutritive value of Leucaena leaf meal in a pelleted feed for Nile tilapia. Aquaculture 1987; 62: 97-108.

11. Hasan MR, Roy PK, Akand AM. Evaluation of leucaena leaf meal as dietary protein source for Indian major carp, Labeo rohita fingerlings. In De Silva, SS (ed). Fish Nutrition Research in Asia. Proceedings of the Fifth Asian Fish Nutrition Workshop. Asian Fish.

12. Tacon AGJ, Jauncey K, Falaye A, Patha M, Macgowan I, Stafford EA. The use of meat and bone meal, hydrolyzed feather meal and soybean meal in practical fry and fingerling diets for Oreochromis niloticus. Int. Symp. (L. Fishelson and Z Youn eds.) Proc. First Int. Symp. Tilapia in Aquaculture. Tel Aviv University Press, Israel. 1984; pp 356-365.

13. Guillaume J. Protein and amino acids. In: Crustacean Nutrition. ' D' Abramo, L.R. Conklin, DE Akiyama, DM (Eds.) Advances in World Aquaculture Society, Baton Rouge, LA. 1997; pp 26-50.

14. Lee PG, Meyers SP. Chemoattraction and feeding stimulation. In: Crustacean Nutrition, D'Abramo, L.R. Conklin, D.E. Akiyama, D.M. (Eds.). Advances in World Aquaculture Vol. 6 World Aquaculture Society, Baton, Rouge, LA. 1997: pp.292-352. 